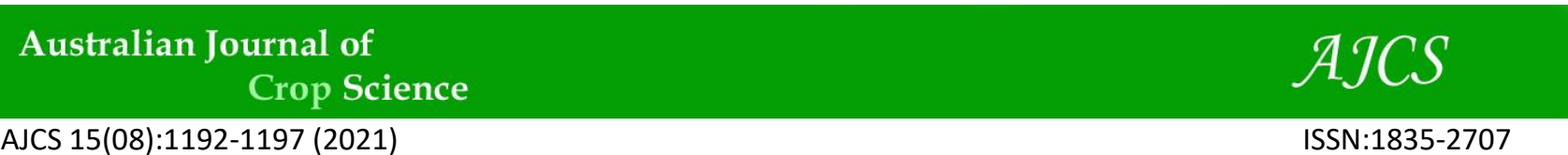

AJCS 15(08):1192-1197 (2021)

ISSN:1835-2707

doi: 10.21475/ajcs.21.15.08.p3320

\title{
Propagation and control of Anredera cordifolia (Ten.) Stennis (madeira vine)
}

\author{
João Paulo R. San Gregorio' ${ }^{1}$ Nicolas Moreira Pioto ${ }^{2}$, Victor Augusto Forti' ${ }^{2}$, Josiane Rodrigues ${ }^{2}$, Paulo \\ Vinicius da Silva ${ }^{3}$, Patricia Andrea Monquero ${ }^{2 *}$
}

\author{
${ }^{1}$ Graduate Program in Agriculture and Environment, São Carlos University, Araras, São Paulo State, Brazil. \\ ${ }^{2}$ Center of Agrarian Sciences, São Carlos University, Araras, São Paulo State, Brazil. \\ ${ }^{3}$ Federal University of Grande Dourados, Dourados, MS, Brazil.
}

*Corresponding author: pamonque@ufscar.br

\begin{abstract}
Anredera cordifolia (Ten.) Stennis, commonly known as the madeira vine, is a succulent vine that produces vegetative structures on stems and invades agricultural areas in Brazil. This plant has become a possible invader in Brazilian agriculture with records of losses in coffee crops. The objective of this study was to study the influence of dimensional variation and different depths of planting aerial bulbils on the growth and development of $A$. cordifolia plants, as well as to study the influence of the effect of herbicides on postemergence control. All experiments were carried out in a greenhouse. In the propagation experiment, a completely randomized design with six replications was used. Aerial tubers of four weight categories (C) (C1, 0-0.59 g; C2, 0.60-1.49 g; C3, 1.50-2.99 g; C4, 3.0-12.0 g) were evaluated regarding the percentage of viable tubers, number of stems per tuber (ST), average stem length, shoot dry matter, and emergence speed index (ESI). ST and ESI were evaluated at seven soil depths $(0,3,6,10,15,20$, and $30 \mathrm{~cm})$. For experiments with herbicides, a completely randomized design with four replications was used. Six herbicides (chlorimuron-ethyl, flumioxazin, glyphosate, metsulfuron-methyl, saflufenacil, and glyphosate + saflufenacil) at the recommended doses and a control (without herbicide) were used to evaluate the postemergence control. Plants from larger tubers had a higher sprouting rate and faster growth and establishment, and tubers grown on the soil surface produced plants with faster development. Glyphosate + saflufenacil was more effective in controlling this plant species, with $79.50 \%$ control. All other herbicide treatments caused only chlorosis and poor control.
\end{abstract}

Keywords: wood vine; chemical control; aerial tuber emergence.

Abbreviations: C_Aerial tuber categories; ST_number of stems per tuber; ESI_emergence speed index.

\section{Introduction}

Anredera cordifolia (Ten.) Stennis, popularly known as Madeira vine in southeast Brazil, is a succulent terrestrial vine native to Bolivia, Paraguay, Uruguay, northern Argentina, and southern Brazil and can invade agricultural areas in different geographical regions and countries (CABI, 2013). A. cordifolia has multiple reproductive strategies but spreads primarily through vegetative growth via aerial tubers and rhizomes (Starr et al., 2003). Aerial tubers have variable sizes and shapes and develop stem nodes and leaf axils (Vieira et al., 2018). Studies that analyzed the effect of environmental factors on the growth, viability, and resource allocation of tubers can help elucidate the population dynamics of this species (Vivian-Smith et al., 2007).

A. cordifolia plants are difficult to control because of some characteristics, including the presence of tubers, waxy and fleshy leaves, and rhizomes that limit the action of herbicides (Starr et al., 2003). The leaves of $A$. cordifolia are waxy and fleshy (Starr et al., 2003), and leaf size varies according to the stage of plant development and geographical region (Vieira et al., 2018).

Chemical control with herbicides has been an important tool for managing weeds in crops and home landscapes for many years. Postemergence herbicides fall into two general categories. Systemic herbicides are absorbed and transported through the plant's vascular system, killing the entire plant. Contact herbicides kill part of the plant in contact with the chemical, but the roots may survive, and the plant may regrow. Broad spectrum (nonselective) herbicides will kill most plants they encounter. Selective herbicides will affect only some plants (Knight et al., 2004).

Flumioxazin and saflufenacil are contact herbicides, i.e., rupture cell membranes and are not translocated in the plant. These herbicides inhibit protoporphyrin oxidase (PROTOX) in chloroplasts, chlorophyll synthesis, and electron transfer (Markwell et al., 2006). The inhibition of Protox disrupts the integrity of the plasma membrane and culminates in the leakage of cellular constituents, including chlorophyll and carotenoids (Vidal, 1997; Hess, 2000; Oliveira Junior and Constantin, 2001).

Metsulfuron-methyl, chlorimuron-ethyl, and glyphosate inhibit enzymes involved in the production of amino acids. Metsulfuron-methyl and chlorimuron-ethyl inhibit the enzyme acetolactate synthase (ALS), which catalyzes the first step in the synthesis of the branched-chain amino acids 
leucine, isoleucine, and valine (Vidal, 1997; Zhou et al., 2007). Glyphosate inhibits the synthesis of the enzyme 5enolpyruvylshikimate-3-phosphate synthase (EPSPS), which catalyzes the synthesis of the aromatic amino acids tyrosine, tryptophan, and phenylalanine, which are precursors to compounds that are essential to plants, including hormones and flavonoids (Stephenson et al., 2006).

This study assessed the effect of the weight of aerial tubers on the growth and development of $A$. cordifolia and the effect of herbicides (chlorimuron-ethyl, flumioxazin, glyphosate, metsulfuron-methyl, saflufenacil, and glyphosate + saflufenacil) on the postemergence control of this plant species.

\section{Results}

\section{Effect of tuber weight on plant growth}

Aerial tubers are reproductive structures that improve the survival and dispersion of $A$. cordifolia. The morphology of tubers of $A$. cordifolia varies widely (Figure 1 ). The percentages of viable C4 and C1 tubers were $100 \%$ and $60 \%$, respectively. C4 tubers produced more than one stem, whereas $\mathrm{C} 1$ and $\mathrm{C} 2$ tubers produced less than one stem. The average stem length (ASL) of plants originating from C4 tubers was similar to that of plants from C3 tubers but was more than fivefold higher than that of $\mathrm{C} 1$ and $\mathrm{C} 2$ tubers (Figure 2). The SDW of plants originating from $\mathrm{C} 4$ tubers was higher than that of plants from the other weight categories. Plants from C4 tubers emerged approximately twice faster, and the ESI was higher than that of plants from $\mathrm{C} 1$ and $\mathrm{C} 2$ tubers (Figure 2).

\section{Effect of planting depth on plant emergence}

The scatter plots showed that the study variables decreased as planting depth increased (Figure 3 ). The number of stems per tuber (ST) and emergence speed index (ESI) decreased as planting depth increased (Figures $3 a$ and $b$ ). Tubers grown at depths greater than $15 \mathrm{~cm}$ did not produce plantlets, and ST and ESI were null at depths deeper than $15 \mathrm{~cm}$.

The tubers with a higher frequency of occurrence had masses varying from 0.03 to $1.49 \mathrm{~g}$ and were classified as classes 1 and 2. C1 and C2 tubers produced fewer seedlings and less than one stem per tuber, and ASL was smaller. Moreover, the biomass and growth of these tubers were smaller than those of the other groups.

Effect of herbicides on the postemergence control of plants The interaction between herbicide and study period $(\mathrm{H} \times \mathrm{P})$ was not significant $(P>0.05)$. Moreover, the effect of herbicides between the study periods was not significant $(P>0.05)$ (Table 1). Therefore, Tukey's test was applied only to the main effect of herbicides.

The effect of herbicides on $A$. cordifolia growth was significant when compared to the control, and approximately $80 \%$ of the plants were controlled by glyphosate + saflufenacil. The second and third most effective herbicides were glyphosate and saflufenacil, respectively. The effectiveness of metsulfuron-methyl, chlorimuron-ethyl, and flumioxazin was less than $6 \%$ (Table 2). No herbicides significantly affected SDW, except for glyphosate + saflufenacil and glyphosate alone, which decreased SDW by more than $80 \%$ compared to the control (Table 2).

\section{Discussion}

\section{Effect of tuber weight on plant growth}

The study variables increased as tuber weight increased, except for SC (Figure 2a). Variability in tuber size was observed in previous studies (Vivian-Smith et al., 2007; Moreira and Bragança, 2011; Vieira et al., 2018), suggesting that this characteristic is inherent to this species and is a reproductive strategy, as the viability and growth of plants originating from larger tubers are higher, whereas smaller tubers are compensated by a greater amount of vegetative material.

Aerial tubers are essential for vegetative growth by allowing the emission of roots and the sprouting of aerial branches (Moreira and Bragança, 2011; Vieira et al., 2018). Vieira et al. (2018) analyzed the anatomical characteristics of $A$. cordifolia tubers and observed tissue-forming regions with meristematic characteristics, suggesting the formation of buds for vegetative sprouting.

The results suggest that larger tubers have more meristematic tissue and, therefore, could be greater chances of producing new plants. The percentages of sprouting of tubers with $>3.00 \mathrm{~g}(\mathrm{C} 4)$ and $<0.60 \mathrm{~g}(\mathrm{C} 1)$ were $100 \%$ and $60 \%$, respectively (Figure $2 b$ ).

ST decreased as the number of plants per tuber increased. The least viable tubers produced less than one stem per tuber. The presence of more than one stem per tuber indicated that tubers within a given weight category produced two or more stems. The ST in tubers larger than $3 \mathrm{~g}$ (C4) and smaller than $1.50 \mathrm{~g}$ ( $\mathrm{C} 1$ and $\mathrm{C} 2$ ) was $>1.0$ and $<0.6$, respectively, and the latter group was not viable (Figure $2 \mathrm{c}$ ). The ability of a tuber of a certain weight category to sprout may be related to anatomical characteristics, suggesting that the variation in tuber weight contributed to the increase in ST and the size of the nutrient reserve. Vieira et al. (2018) found that amyloplasts were abundant in the parenchyma of aerial tubers, suggesting the storage function of this organ.

In A. cordifolia, leaves and tubers are formed in stems. Stems allow plant establishment and growth in areas with favorable environmental conditions. The vertical and horizontal displacement of $A$. cordifolia plants is closely related to ASL such that plants with higher ASL can find better conditions for survival and propagation.

Although tubers larger than $1.50 \mathrm{~g}$ ( $\mathrm{C} 3$ and $\mathrm{C} 4)$ had stems approximately five times larger than those of tubers smaller than $1.50 \mathrm{~g}$ (C1 and C2) (Figure 2d), stem length was shorter than that reported by Cummings (1999), in which the average length was $106.6 \mathrm{~cm}$ in A. cordifolia tubers grown in a greenhouse for 8 weeks in the summer period. Vieira et al. (2018) performed morphological characterization of $A$. cordifolia and found that stem length was variable, suggesting that this characteristic was inherent to the species.

The aerial parts of $A$. cordifolia plants include stems, leaves, inflorescences, and aerial tubers. At the end of the study period, stems and leaves were collected. SDW indicates plant growth, i.e., an increase in biomass. Larger tubers produced plants with higher SDW (Figure 2e).

Leaves are responsible for the photosynthetic capacity of $A$. cordifolia plants and affect the adaptive and productive potential of a plant species. A. cordifolia plants have high biomass production capacity. Botrel et al. (2017) showed that the biomass produced per plant is $100-200 \mathrm{~g}$ per month. Leaves constitute a large part of the biomass and are crucial for plant growth and development. Previous studies have 
Table 1. Postemergence control of Anredera cordifolia plants by herbicides using a completely randomized block design in a $6 \times 5$ factorial scheme (herbicides $\times$ study periods). Data were analyzed using analysis of variance at a level of significance of $5 \%$.

\begin{tabular}{|c|c|c|c|c|c|}
\hline & DF & seq SS & adj SM & F-value & $p$-value \\
\hline Herbicides $(\mathrm{H})$ & 5 & 131.62 & 26.33 & 25.73 & $0.00 *$ \\
\hline Periods (P) & 4 & 7.94 & 1.98 & 1.94 & 0.11 \\
\hline $\mathrm{H} \times \mathrm{P}$ & 20 & 18.08 & 0.90 & 0.88 & 0.61 \\
\hline Error & 90 & 92.08 & 1.02 & & \\
\hline Total & 119 & 249.73 & & & \\
\hline
\end{tabular}

C1

C2

C3

C4
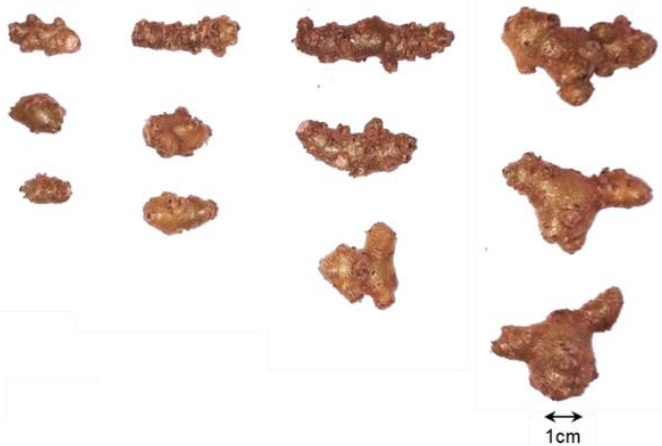

Figure 1. Aerial tubers of Anredera cordifolia collected in a coffee plantation located between the municipalities of Caconde, São Paulo, and Poços de Caldas, Minas Gerais, Brazil, and classified into four weight categories (C1, 0-0.59 g; C2, 0.60-1.49 g; C3, 1.50-2.99 g; C4, 3.0-12.0 g)

Table 2. Effect of herbicide application at the recommended doses on the postemergence control of Anredera cordifolia plants over a 5-week period. C, percentage of control according to the scale proposed by ALAM (1974); SDW, shoot dry weight.

\begin{tabular}{|l|l|l|l|}
\hline Treatment & \multicolumn{2}{l|}{ C-ALAM $(1974)(\%)+$} & SDW (g) \\
\hline Glyphosate + saflufenacil & 79.50 & $\mathrm{a}$ & 0.52 \\
\hline Glyphosate & 12.00 & $\mathrm{~b}$ & 0.95 \\
\hline Saflufenacil & 9.75 & $\mathrm{c}$ & 1.38 \\
\hline Metsulfuron-methyl & 5.75 & $\mathrm{~d}$ & 2.50 \\
\hline Chlorimuron-ethyl & 5.50 & $\mathrm{~d}$ & 1.26 \\
\hline Flumioxazin & 5.00 & $\mathrm{~d}$ & 1.21 \\
\hline Control & 0.00 & $\mathrm{e}$ & 4.08 \\
\hline CV (\%) & 69.50 & & 41.26 \\
\hline MSD & 0.95 & & - \\
\hline
\end{tabular}

+Different letters in each column indicate significant differences between the means using Tukey's test at a level of significance of 5\%. 9The means were not different using the $F$ test (ANOVA) at a level of significance of $5 \%$. CV coefficient of variation. MSD, minimum significant difference.
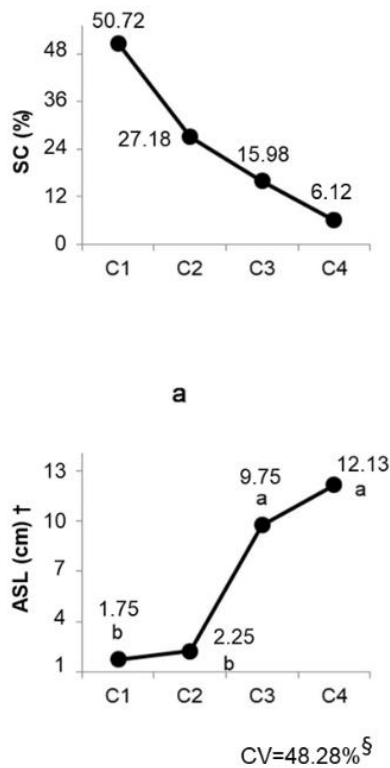

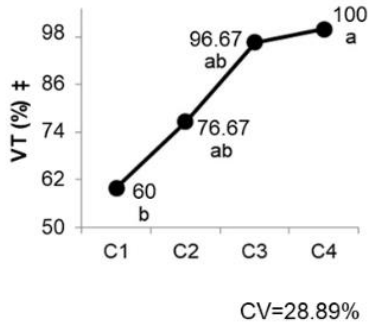

b

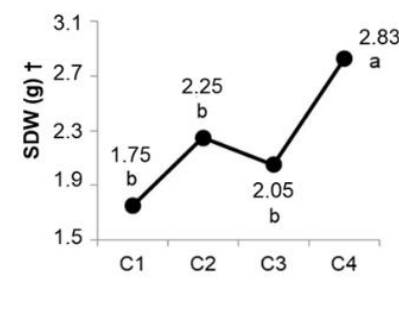

$C V=51.21 \%$

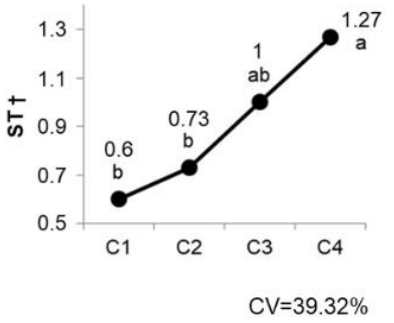

C

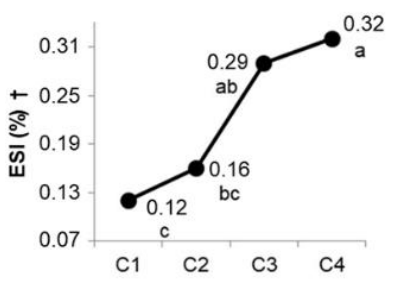

$\mathrm{CV}=55.83 \%$

f

Figure 2. Growth and development of $A$. cordifolia plants with tubers from four weight categories (C1, 0-0.59 g; C2, 0.60-1.49 g; C3, 1.50-2.99 g; C4, 3.0-12.0 g) planted in trays in a greenhouse in the municipality of Araras, São Paulo, Brazil. a. Sample composition (SC). b. Percentage of viable tubers (VT). c. Number of stems per tuber (ST). d. Average stem length (ASL). e. Shoot dry weight (SDW). f. Emergence speed index (ESI). †Different letters in each column indicate significant differences between the means using Tukey's test at a level of significance of $5 \%$. $¥$ Different letters in each column indicate significant differences between the means using the Nemenyi test at a level of significance of 5\%. §Coefficient of variation using the Box and Cox transformation (1964). 


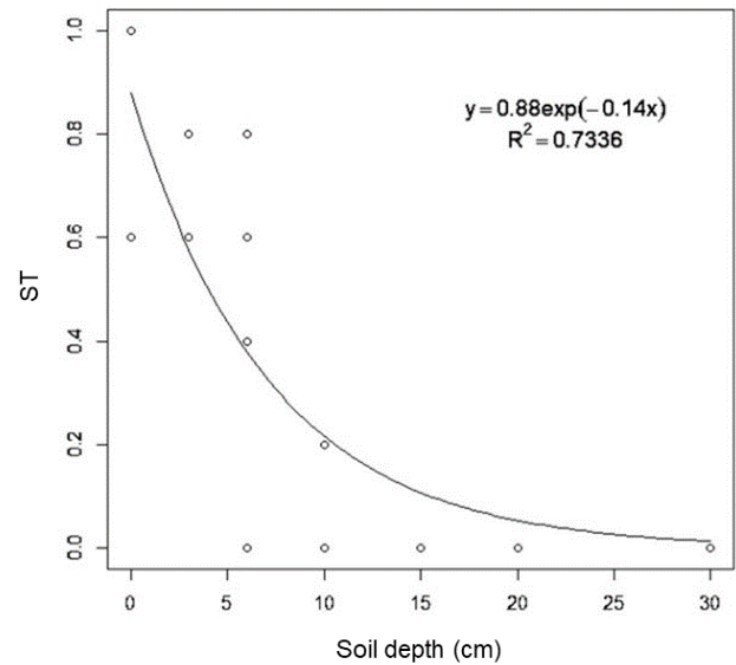

a

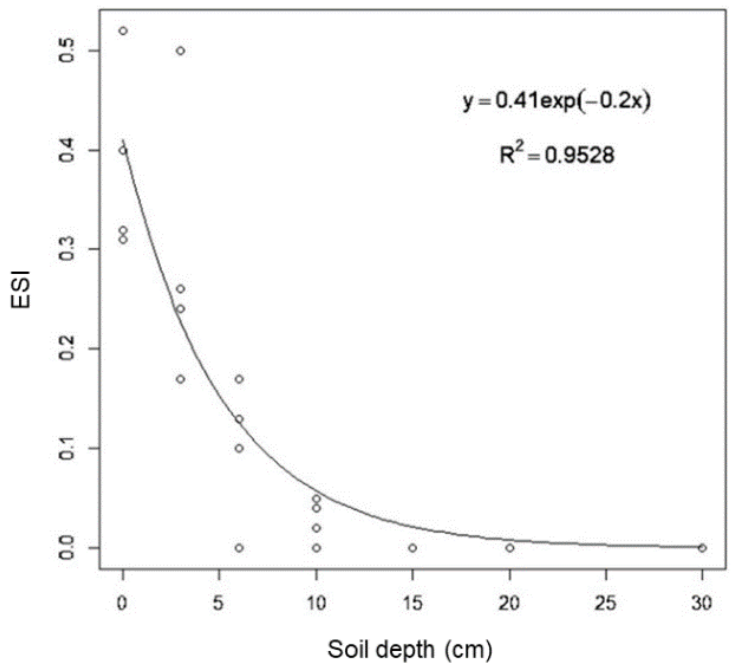

b

Figure 3. Regression curve: a. Number of stems per tuber (ST). b. Emergence speed index (ESI) of Anredera cordifolia plants grown at different soil depths $(0,3,6,10,15,20$, and $30 \mathrm{~cm})$ in a greenhouse in Araras, São Paulo, Brazil.

shown that both sides of the leaves of $A$. cordifolia have stomata (Boyne et al., 2013; Vieira et al., 2018). Given that stomata control water loss from transpiration during the capture of carbon dioxide for photosynthesis and play an important role in the physiological performance and adaptative capacity of plants, Osunkoya et al. (2014) suggested that the invasive capacity of this species could be explained by the size and presence of stomata on both sides of leaves.

The ESI indicates the ability of tubers to produce new plants and is directly related to colonization capacity. Rapid initial development guarantees the use of resources essential to plant growth and development, including water and nutrients. In addition, rapid emergence reduces the likelihood of adverse conditions and herbivore damage, which limits the formation of seedlings.

Tubers larger than $3.0 \mathrm{~g}(\mathrm{C} 4)$ produced plants twice as quickly as tubers smaller than $0.60 \mathrm{~g}$ (C1) (Figure 2f). Larger tubers grow rapidly and have higher establishment capacity, which improves plant adaptation and survival.

\section{Effect of planting depth on plant emergence}

ST decreased as planting depth increased. Aerial tubers sprout in stem nodes and leaf axils and, upon detaching from the stem, produce roots and stems (Vieira et al., 2018), suggesting that vegetative growth starts with the establishment of tubers on the soil surface or at low depths. ST increased as planting depth decreased.

As planting depth increased, the energy requirement for sprouts to reach the soil surface increased, and microbial activity might be higher because of increased soil moisture, potentially reducing tuber viability.

The speed at which aerial tubers sprouted was also affected by planting depth. Tubers located on the soil surface produced plants more quickly than those located at deeper depths. The increase in planting depth decreased the speed of tuber production. However, tuber mortality was not determined.

Effect of herbicides on the postemergence control of plants Postemergence control was not effective using only one herbicide class, with maximum control of up to $12 \%$, suggesting that morphophysiological characteristics of leaves could inhibit the action of herbicides. Webb and Harrington (2005) analyzed the control of $A$. cordifolia and found that the effectiveness of herbicides was highest after 12 months of application, with maximum effectiveness using metsulfuronmethyl at doses of $0.2-0.3 \mathrm{~g}$ a.i. $\mathrm{L}^{-1}$ and glyphosate at $1.8 \mathrm{~kg}$ a.i. $\mathrm{L}^{-1}$ combined with silicate nanoparticles as adjuvant in the spray solution. Aerial tubers were planted in bags containing a peat mixture. Adjuvants increase herbicide penetration by increasing the surface area of spray droplets, suggesting that the adjuvant improved the performance of metsulfuronmethyl and glyphosate in controlling $A$. cordifolia.

The effectiveness of glyphosate + saflufenacil, glyphosate, and saflufenacil was $80 \%, 12 \%$, and $10 \%$, respectively, suggesting that the herbicide mixture acted synergistically. Similarly, Dalazen et al. (2015) found a synergistic relationship between glyphosate and saflufenacil for the control of hairy fleabane (Conyza bonariensis). Eubank et al. (2013) observed that saflufenacil increased the absorption of glyphosate by $C$. canadenses. Dalezen et al. (2015) reported that saflufenacil increased the translocation of glyphosate in the plant.

In our sample, the effectiveness of flumioxazin and saflufenacil was low in the first weeks of evaluation, a period in which a high rate of control was expected, and the plants recovered from phytotoxicity over time.

The effectiveness of metsulfuron-methyl and chlorimuronethyl was low until week 7 after application. Peterson et al. (2001) found that the damage caused by ALS-inhibiting herbicides was not apparent until several days after treatment. Moreover, plant damage was more evident from days 3 to 5 after glyphosate application and occurred slowly, 
suggesting that a longer study period would be necessary to evaluate the effectiveness of these herbicides. The ability of A. cordifolia to metabolize herbicides may contribute to the low effectiveness of control of this species. However, there is no evidence in this work to corroborate this claim.

Another important factor is herbicide selectivity to crops infected by $A$. cordifolia. This plant species has been found in coffee plantations in the states of São Paulo and Minas Gerais, Brazil. Nonetheless, Moreira and Bragança (2011) observed that this species also affected citrus and other fruit trees. No herbicides available in Brazil are registered for the control of $A$. cordifolia. Therefore, our data can serve as the basis for future studies.

Herbicides did not significantly affect SDW, except for glyphosate + saflufenacil and glyphosate, which decreased SDW by approximately $90 \%$ and $75 \%$, respectively, when compared to the control.

Since leaves constitute a large part of plant biomass and are essential for the growth and development of $A$. cordifolia, SDW could corroborate the results on the percentage of control because these data are based on visual assessment using the scale proposed by ALAM (1974), given that the effect of herbicides on SDW was not significant.

Plants from larger tubers established and grew rapidly. However, SC suggests that few tubers had a large weight and many tubers had a small weight. Aerial tubers grown on the soil surface had a greater chance of producing plants with rapid growth. Glyphosate + saflufenacil controlled $80 \%$ of $A$. cordifolia plants. The evaluated herbicides were not effective in the postemergence period.

\section{Materials and methods}

\section{Collection and classification of plant material}

Aerial tubers were collected at random from the stems of vines in a coffee plantation located between Caconde, São Paulo, and Poços de Caldas, Minas Gerais, Brazil in 2018 and 2019. Tubers were classified by weight. Few studies have analyzed the propagation of $A$. cordifolia, and tuber size has not been standardized because shape and size are highly variable. The study sample contained 1045 tubers, which were classified into the following weight categories (C): C1 (0$0.59 \mathrm{~g}), \mathrm{C} 2(0.60-1.49 \mathrm{~g}), \mathrm{C} 3(1.50-2.99 \mathrm{~g})$, and C4 (3.0-12.0 g). The $95 \%$ confidence intervals were calculated.

\section{Experiments}

The experiments were conducted in a greenhouse in the municipality of Araras (latitude, $22^{\circ} 18^{\prime} 49.5^{\prime \prime} \mathrm{S}$; longitude, $47^{\circ} 23^{\prime} 03.8^{\prime \prime}$ W), São Paulo, Brazil, in the summer of 2018/2019. Two experiments were performed to evaluate the growth and development of $A$. cordifolia plants from each weight category, and one experiment was conducted to assess the effect of herbicides on the postemergence control of plants, which were sprinkler irrigated at a flow rate of $72 \mathrm{~L}$ $\mathrm{h}^{-1}$ in 10-min sessions at 8:00 am, 11:00 am, 3:00 pm, and 6:00 pm.

\section{Effect of tuber weight on plant growth}

An experimental unit consisted of $2.5 \mathrm{~L}$ tray $(20 \times 30 \times 5 \mathrm{~cm})$ filled with dark red latosol soil with a clayey texture that was collected at a depth of $0-20 \mathrm{~cm}$ in an agricultural field not sprayed with herbicides. Tubers were planted at a soil depth of $3 \mathrm{~cm}$. Each replicate contained five tubers spaced $4 \mathrm{~cm}$ apart. The experiment lasted 9 weeks.
During the study period, the percentage of viable tubers (VT) was evaluated, and seedlings taller than $0.5 \mathrm{~cm}$ were considered emerged; number of stems per tuber (ST); average stem length (ASL); shoot dry weight (SDW), in which the plants were dried in an oven at $60{ }^{\circ} \mathrm{C}$ for $48 \mathrm{~h}$; and emergence speed index (ESI) using the formula proposed by Maguire (1962) as the ratio between the number of plants that emerged in count $1,2 \ldots, n$, and the number of days from planting to count $1,2 \ldots, \mathrm{n}$ : Rate $=$ number of normal seedlings/days to first count $+\ldots+$ number of normal seedlings/days to final count +.+ number of normal seedlings/days to final count

\section{Effect of planting depth on plant emergence}

Experimental units were made up of polyethylene pots with a $30 \mathrm{~L}$ capacity. The study used a completely randomized design with four replicates at each soil depth $(0,3,6,10,15$, 20 , and $30 \mathrm{~cm}$ ). The effects of depth on plant growth and development were evaluated.

Tubers were planted at a soil depth of $3 \mathrm{~cm}$. Each replicate contained five tubers spaced $4 \mathrm{~cm}$ apart (Figure 3). Planting depth was measured using a ruler. Aerial tubers with a higher frequency of occurrence, i.e., weight between 0.03 and 1.49 $\mathrm{g}$, were selected for planting. Seedlings higher than $0.5 \mathrm{~cm}$ were considered emerged. The experiment lasted 7 weeks. ST at each planting depth, average ST, and ESI were calculated.

\section{Effect of herbicides on the postemergence control of plants}

Experimental units were made up of polyethylene pots with a $10 \mathrm{~L}$ capacity. Tubers were planted at a soil depth of $3 \mathrm{~cm}$, and each replicate contained five tubers spaced $4 \mathrm{~cm}$ apart. The herbicides were applied 3 months after planting, and the plants were trimmed to maintain a density of four plants per pot. Herbicides (chlorimuron-ethyl [ $20 \mathrm{~g}$ a.i. ha ${ }^{-1}$ ], flumioxazin [25 g a.i. ha-1 $]$, glyphosate [2.400 g a.i. ha-1 ${ }^{-1}$, metsulfuronmethyl [6 g a.i. ha-1], saflufenacil [70 g a.i. ha-1], and glyphosate + saflufenacil [1.440 g a.i. ha-1 +49 g a.i. ha-1]), and a control without herbicide) were applied using a backpack $\mathrm{CO}_{2}$-pressurized sprayer with constant pressure, with a Teejet 11002 nozzle, pressure of $2.0 \mathrm{kgf} \mathrm{cm}^{-2}$, and a total spray volume of $200 \mathrm{~L} \mathrm{ha}^{-1}$. At the time of application, the average temperature was $27.3^{\circ} \mathrm{C}$, the relative humidity was $35 \%$, and the average wind speed was $0.7 \mathrm{~m} \mathrm{~s}^{-1}$.

The effect of herbicides was assessed over a 5-week period. Assessments were based on qualitative criteria, according to ALAM (1974), using a percentage scale, in which zero corresponded to the absence of injuries and 100 represented plant death. At 5 weeks after herbicide application, the aerial part of the plants was harvested, and the shoot dry weight (SDW) was determined by drying in a forced-air oven $\left(60^{\circ} \mathrm{C}+/-\right.$ $2{ }^{\circ} \mathrm{C}$ ) until a constant weight.

\section{Statistical analyses}

\section{Effect of tuber weight on plant growth}

The experimental design was completely randomized, with six replicates of each of the four weight categories. The data were subjected to analysis of variance (ANOVA) with Box-Cox transformation for nonnormal and/or heteroscedastic data. The means were compared using Tukey's test at a level of significance of $5 \%$. Data that did not meet ANOVA assumptions, even after performing the Box-Cox transformation, were analyzed using the Kruskal-Wallis nonparametric test at a level of significance of $5 \%$. The means 
were compared using the Nemenyi nonparametric test at a level of significance of $5 \%$. Statistical analysis was performed using R software - version 3.1-131 (R Core Team, 2017).

\section{Effect of planting depth on plant emergence}

The study used a completely randomized design with four replicates. The effect of each variable at each planting depth was determined by regression analysis. Statistical analyses were performed using R software - version 3.1-131 (R Core Team, 2017).

\section{Effect of herbicides on the postemergence control of plants} The study used a completely randomized block design in a 6 $\times 5$ factorial scheme with four replicates to assess the effects of six herbicides at recommended doses on the postemergence control of plants over a 5 -week period. The data were subjected to ANOVA. Log $(x+1)$ transformation was performed for nonnormal and/or heteroscedastic data. The means were compared using Tukey's test at a level of significance of $5 \%$. Statistical analysis was performed using R software - version 3.1-131 (R Core Team, 2017).

\section{Conclusion}

Tubers larger than $3.0 \mathrm{~g}$ produced plants twice as quickly as tubers smaller than $0.60 \mathrm{~g}$. Larger tubers grow rapidly and have higher establishment capacity, which improves plant adaptation and survival. Tubers located on the soil surface produced plants more quickly than those located at deeper depths. Glyphosate + saflufenacil controlled $80 \%$ of $A$. cordifolia plants, and all other herbicides were not effective in the postemergence period.

\section{Acknowledgments}

To the Coordination of Improvement of Higher Education Personnel (Coordenação de Aperfeiçoamento de Pessoal de Nivel Superior-CAPES) for funding this research.

\section{References}

Asociación Latinoamericana de Malezas, ALAM (1974) Recomendaciones sobre unificacion de los sistemas de evaluacion en ensayos de control de malezas. ALAM. 1: 35-38

Botrel N, Madeira NR, Melo RAC, Amaro GB (2017) Hortaliças não convencionais: Anredera. EMBRAPA Hortaliças - folder (INFOTECAE). Available from URL: https://www.infoteca.cnptia.embrapa.br/handle/doc/1071381. Accessed 20 August 2019.

Box GEP, Cox DR (1964) An analysis of transformations. J. of the Stat. Roy. Soc. 26: 211-252.

Boyne R L, Osunkoya OO, Scharaschkin T (2013). Variation in leaf structure of the invasive madeira vine (Anredera cordifolia) at different light levels. Am J Bot. 61: 412-417.

Cabi - Centre for Agriculture and Bioscience International (2013) Invasive Species Compendium: Anredera cordifolia (Madeira vine). Available from URL: https://www.cabi.org/isc/datasheet/112290. Accessed 10 August 2019.

Coupland D (1985) Metabolism of glyphosate in plants. In: Grossbard E, Atkinson D (eds) The herbicide glyphosate. Butterworth, London. p. 25-33.
Cummings $S$ (1999) The invasion potential of scrambling environmental weeds. B.App.Sc. (Honours) Thesis, Griffi th University, Nathan, Queensland.

Dalazen G, Kruse ND, Machado SLDO, Balbinot A (2015) Sinergismo na combinação de glifosato e saflufenacil para o controle de buva. (In Portuguese, with English abstract.) Pesq Agropecu Trop. 45: 249-256.

Dyer WE (1994) Resistance to glyphosate. In: Powles SB, Holtum JAM (eds). Herbicide resistance in plants. Boca Raton: CRC Press. p. 229241.

Eubank TW, Nandula VK, Reddy KN, Poston DH, Shaw DR. (2013). Saflufenacil efficacy on horseweed and its interaction with glyphosate. Weed Biol Manag. 13: 135-143.

Hess, FD (2000) Light-dependent herbicides: an overview. Weed Sci. 48: $160-170$.

Knight JS. Hauxwell EAH (2014) Distribution and abundance of aquatic plants - human impacts., Earth Sys. and Env. Sci. 1: 45-54.

Maguire JD (1962) Speed of germination-aid in selection and evaluation for seedling emergence and vigor. Crop Sci. 2: 176-177.

Marchi G, Marchi ECS, Guimarães TG (2008) Herbicidas: mecanismos de ação e uso. Embrapa Cerrados-Documentos (INFOTECA-E). Available from URL: https://www.infoteca.cnptia.embrapa.br/bitstream/doc/571939/ 1/doc227.pdf. Acessed 20 August 2019.

Markwell J, Namuth D, Hernandez-Rios I (2006) Introducción a los herbicidas que actúan a través de la fotosintesis. 2006. Disponível em: <http:// plant and soil.unl.edu/croptechnology2005/weed_science/>. Acessed 21 jan. 2019.

Moreira HJC, Bragança HBN (2011) Manual de identificação de plantas infestantes: Anredra cordifolia. FMC Agricultural Products, 204-205. Available from URL: https://bibflora.medialab.ufg.br/wpcontent/uploads/2017/05/manual_de_identificacao_de_plantas_i nfestantes_hortifruti.pdf. Accessed 20 August 2019.

Oliveira Junior RD, Constantin J (2001) Plantas daninhas e seu manejo. Guaíba: Agropecuária. 361p.

Osunkoya OO, Boyne RL, Scharaschkin T (2014) Coordination and plasticity in leaf anatomical traits of invasive and native vine species. Am J Bot. 101: 1423-1436.

Peterson D E, Thompson CR, Regehr DL, Al-Khatib K (2001) Herbicide mode of action. Topeka: Kansas State University, 24 p.

R Core Team. (2017) R: A Language and Environment for Statistical Computing. R Foundation for Statistical Computing.

Starr F, Starr K, Loope L (2003) Anredera cordifolia. United States Geological Survey Biological Resources Division, Haleakala Field Station. Available from URL: http://hear.org/starr/hiplants/reports/pdf/anredera_cordifolia.pd f. Accessed on 20 August 2019.

Stephenson GR, Ferris IG, Holland PT, Nordberg M (2006) Glossary of terms relating to pesticides (IUPAC Recommendations 2006). Pure and Appl Chem. 78: 2075-2154.

Vidal A. R (1997) Herbicidas: Mecanismos de ação e resistência de plantas. Porto Alegre, RS, BR. 120p.

Vieira ACM, Conceição CCN, Moura MRL, Soares NF, Emídio RL, Almeida TVPA (2018) Manual sobre plantas alimentícias não convencionais: Bertalha menor (Anredera cordifolia (Ten.) Steenis): estudo morfológico, anatômico, microquímico e bromatológico. Cerceav. 1: 80-122.

Vivian-Smith G, Lawson BE, Turnbull I, Downey PO (2007) The biology of Australian weeds. 46. Anredera cordifolia (Ten.) Steenis. Plant Prot Quart. 22: 2-8.

Webb HJ, Harrington KC (2005) Control strategies for Madeira vine (Anredera cordifolia). N. Z. Plant Protect. 58:169-173.

Zhou Q, Liu W, Zhang Y, Liu K K (2007) Action mechanisms of acetolactate synthase-inhibiting herbicides. Pestic Biochem Phys. 89: 89-96. 